\begin{abstract}
Iranica
Abstracta Iranica Revue bibliographique pour le domaine irano-aryen

Volume 32-33 | 2013

Comptes rendus des publications de 2009-2010
\end{abstract}

\title{
Barbara D. Metcalf (ed.). Islam in South Asia in Practice
}

\section{Mauro Valdinoci}

\section{(2) OpenEdition \\ 1 Journals}

\section{Electronic version}

URL: http://journals.openedition.org/abstractairanica/40637

DOI: 10.4000/abstractairanica.40637

ISSN: 1961-960X

Publisher:

CNRS (UMR 7528 Mondes iraniens et indiens), Éditions de l'IFRI

\section{Printed version}

Date of publication: 1 December 2013

ISSN: 0240-8910

\section{Electronic reference}

Mauro Valdinoci, «Barbara D. Metcalf (ed.). Islam in South Asia in Practice », Abstracta Iranica [Online], Volume 32-33 | 2013, document 280, Online since 01 July 2016, connection on 29 September 2020 URL : http://journals.openedition.org/abstractairanica/40637; DOI : https://doi.org/10.4000/ abstractairanica. 40637

This text was automatically generated on 29 September 2020.

Tous droits réservés 


\title{
Barbara D. Metcalf (ed.). Islam in South Asia in Practice
}

\author{
Mauro Valdinoci
}

\section{REFERENCES}

Barbara D. Metcalf (ed.). Islam in South Asia in Practice. Princeton, Princeton University Press, 2009, 474 p., glossary, index.

1 This edited volume contains contributions from scholars of various disciplines, mostly history, anthropology, religious and Islamic studies. Its thirty-four chapters are grouped in five parts, and preceded by a preface and an introduction. In the preface, the editor announces the key methodological issues related to the study of Islam that surface throughout the book; and in the introduction, she provides a historical overview of Islam in South Asia from the seventh century to the period following independence.

2 The first part, "Devotion and praise: To Allah, Muhammad, Imams, and Elders", discusses religious devotion by examining devotional stories and songs written in vernacular languages, religious chromolithographs and practices such as pilgrimages and visits to the tombs of pious men. Each chapter in the second part, "Holy and exemplary lives", is dedicated to a religious figure in order to illustrate his relationship with followers and disciples. Differences are pointed out between pious men, especially with regard to their observance of Islamic law and their social roles. The third section, "The transmission of learning", explores how knowledge of Islamic sacred texts, ritual practices and spiritual exercises has been communicated. Its chapters examine educational texts as well as modern institutions (such as the formally organized madrasa), a mass-based preaching movement and a local cell of Jamāt $t-i$ Islami . The fourth section, "Guidance, sharia and law", focuses on the institutions that use the sharia to decide correct Islamic behavior, such as the qā $\bar{i} \bar{i}$, and, too, on colonial and postcolonial secular courts, informal courts, advisory opinions (sing. fatwā) and a new 
style of popular leaders active in the mass media. The fifth part, "Belonging", addresses the issue of the authorities and arguments that define the basis of the community. Its chapters deal with a wide range of subjects, such as the role of Sufi masters in organizing the social and economic foundations of local Muslim societies, a 16thcentury courtier's opposition to the Islamic legitimacy of the Mogul emperor Akbar, and the articulation of Muslim identity in an Arabic text from 16th-century Malabar.

With its emphasis on the need to study Islam "in practice", this volume seeks to counter the assumption "that a given religion presents timeless universals or positions that hold in all times and places" (p.xix). The editor claims that the failure to study Islamic rituals, traditions and institutions in context has generated distortions in the understanding of Islamic beliefs and practices. She thus criticizes the prevalent approaches in studies of south Asian Islam, which she calls narratives of "conquest" and narratives of "domestication" (p.xix-xxii): the former presenting Muslims as foreign conquerors in India, the latter describing the Muslim presence in the Indian subcontinent mainly as a peaceful accommodation to local practices that is often called "syncretic". The editor's thesis receives confirmation from contributions in the volume, which provide several examples of the blurring of presumed boundaries and the changing of rituals, traditions and institutions over time. Challenging the notion that a closed set of beliefs can explain all Muslim actions, the volume convincingly argues for 'the importance of studying Islam 'in practice' - in specific times and places and contexts - and not from any hermetic notion that 'Islam' can be reduced to transparent and undeviating sacred texts or common mindsets” (p. 374).

\section{AUTHORS}

\section{MAURO VALDINOCI}

University of Modena and Reggio Emilia 